\title{
The Legacy of Andries Nentjes
}

\section{Edwin WOERDMAN}

Groningen University, The Netherlands

Yoram KROZER

\author{
Sustainable Innovations Academy, Amsterdam, The Netherlands \\ Johannes (Joost) PLATJE \\ WSB University in Wroclaw, Poland
}

\begin{abstract}
:
Aim: The aim of this paper is to provide a brief overview of the life and work of Professor Andries Nentjes, who passed away early 2019. As one of the founding fathers of environmental economics in the Netherlands, he contributed in particular to the international literature on market-based pollution control. We wish to honour the legacy of Andries Nentjes by outlining some highlights of his impressive academic research and by showcasing his active contributions to a more sustainable society.
\end{abstract}

\section{Professor Andries Nentjes}

Andries Nentjes was Professor of Economics and Public Finance at the University of Groningen in the Netherlands, during more than thirty years. Professor Nentjes, who preferred to be called 'Andries', passed away in Roden in the Netherlands on the 15th of March 2019, at the age of 80. He is one of the pioneers of environmental economics in the Netherlands. Nentjes published on a wide range of subjects, varying from Keynes to social security to emissions trading, while his genuine kindness made him a much-appreciated colleague and friend.

Correspondence address: Edwin WOERDMAN, Groningen University, The Netherlands. E-mail: e.woerdman@rug.nl (Edwin WOERDMAN), krozer@xs4all.nl (Yoram KROZER), Johannes (Joost) PLATJE (Johannes.platje@wsb.wroclaw.pl.

Received: 21.09.2020, Accepted: 21.09.2020

doi: http://dx.doi.org/10.29015/cerem.889 


\section{Economist at the University of Groningen}

Andries Nentjes was born in Ommen, a small Hanseatic city in the eastern Netherlands, on the 9th of July 1938. After growing up in a Protestant family, he married to Hendrikje ('Hennie') Frijlink with whom he spent his entire life, mostly in Roden, a small village close to the city of Groningen. Andries and Hennie had three children (Marijne, Ide and Andrea) and they were blessed with five grandchildren.

The University of Groningen in the Netherlands is the home and heart of Andries Nentjes' academic career. After studying economics in Groningen, Nentjes published a dissertation in 1977 on Keynes' theory of employment, which had been supervised by the renowned Professor Jan Pen. Nentjes became Professor of Economics in Groningen in 1979, focusing on social security issues at the Faculty of Social Sciences. In 1985 he was appointed Professor of Economics and Public Finance at the Faculty of Law, where he would stay until his retirement.

\section{Keynes, growth and the environment}

His celebrated academic work encompasses the history of economic thought, macroeconomics, post-Keynesian theories and his favorite subject: environmental economics. Andries Nentjes is considered to be a founding father of environmental economics in the Netherlands.

Professor Nentjes made several novel and important contributions to the literature. His paper with Simon Kuipers (1973), that elaborated the relation between increasing costs of pollution and limits to economic growth, triggered new research. This innovative paper on sustainable growth showed that specific conditions need to be fulfilled regarding technical progress in order to prevent economic stagnation. Andries Nentjes (1990) also contributed to the literature with his non-linear model of international environmental cooperation, which generates a Pareto-efficient exchange of emission reduction commitments between countries. Much of his subsequent research would be devoted to the economic analysis of instruments for environmental policy, including emissions taxation and tradable emission rights. In 


\section{THE LEGACY OF ANDRIES NENTJES}

the early nineties, there was very limited experience with emissions trading. Nentjes performed numerous studies on emissions trading design, applied to the European legal context. An early example of this is his paper with Paul Koutstaal (1995) on tradable carbon permits in Europe, which includes a comparison with carbon taxes. Next to that, Nentjes also contributed to analyses of policies on acid rain, environmental innovation and water management, just to name a few examples.

At the Faculty of Law in Groningen, Professor Nentjes supervised several $\mathrm{PhD}$ candidates who wrote dissertations in the field of environmental economics, including Paul Koutstaal, Ger Klaassen, Yoram Krozer, Bouwe Dijkstra, Frans de Vries, Edwin Woerdman and many others. All former $\mathrm{PhD}$ candidates of Andries share a warm feeling about his supervision, which was friendly, supportive and intellectually sharp. Together with these and other scholars, Nentjes published in various renowned journals such as Environmental and Resource Economics, the Journal of Institutional and Theoretical Economics, the Review of Law and Economics, the European Journal of Law and Economics, and Public Choice. This tactile legacy underlines the outstanding quality of his academic work.

Nentjes could excel in research because of his above-average intelligence, his superb mastery of economics and his much-appreciated organization and communication skills. His ability to attract funding for $\mathrm{PhD}$ candidates also helped him to advance his own research, not only by publishing together with them but also by dividing the more mundane tasks, such as checking exams, over more people.

Another relevant but less well-known explanation for his success is that he had very little teaching duties at the Faculty of Law as well as limited household tasks at home. While his wife Hennie ran the household and shouldered most caring responsibilities of their children, Pierre Eijgelshoven agreed with Andries to do most of the lecturing in law and economics. Pierre was Associate Professor and a talented teacher, while Andries was a strong researcher. As an efficient form of Coasean bargaining, Pierre agreed to focus almost solely on teaching so that Andries could spend more time on research. A win-win deal that would be almost unimaginable in today's academia, where both professors, associates and assistants are pressured to publish regularly in international peer-reviewed journals and to increase the number of contact hours with their students, against the backdrop of (at least somewhat) 
more equally divided caring duties at home. Andries realized that he was in a fortunate position which helped him to thrive as an academic.

\section{Environmental activist with royal distinction}

Next to his genuine interest in science and academia, Andries Nentjes also wanted to use his knowledge to protect ecosystems and combat pollution, both in the Netherlands and beyond (as shown in a nice overview in Dutch made by Frans Oosterhuis, 2018). Andries Nentjes was, among others, an active board member of the Landelijke Vereniging tot Behoud van de Waddenzee (1972-1987), a member of the Centrale Raad voor het Milieubeheer (1979-1985), co-founder and chair of the Economenwerkgroep Landelijk Milieu Overleg (1980-1992), and member of the Algemene Energie Raad (1985-1991). As an environmental voluntarist in front of the European Parliament and the Dutch government, Andries fostered environmental organizations, green business development and low-carbon policymaking.

Even at home he preferred to protect the environment and enjoy nature by working in his own garden, which was one of his major hobbies. As a consequence, Andries could show up at the university in a nice suit, but still wearing wool socks with his hands showing traces of work in the garden.

Andries Nentjes described himself as "de economist, die in zijn hart milieuactivist bleef" (Nentjes, 2017), which can be translated as 'the economist, who remained an environmentalist at heart'. Because of his contributions to science and society, Professor Nentjes was honoured with a royal distinction in 2004, when he was appointed Officer in the Order of Orange Nassau (Orde van Oranje Nassau).

\section{Energetic emeritus professor}

Also after his retirement, when he received emeritus status, Andries Nentjes stayed active in environmental economics with various publications and conference presentations. In fact, as he felt relieved from the burdensome administrative tasks he had to perform at the Faculty, he enjoyed his scientific work in economic science even more, next to gardening. 


\section{THE LEGACY OF ANDRIES NENTJES}

This is exemplified by the fact that the fruits of his post-retirement labour are still being published, even after his death. Examples are his recent work on hybrid forms of emissions trading (together with Edwin Woerdman, 2019), and his work on Pareto-efficient solutions for the shared provision of public goods (together with Bouwe Dijkstra, 2020).

\section{The revival of ISINI}

Andries Nentjes also helped to revive the International Society for the intercommunication of New Ideas (ISINI). After a couple of years when ISINI conferences were no longer being organized, his then-ill friend and ISINI Board Member Professor Gerrit Meijer asked Andries to help with organizing the 12th International Meeting of ISINI in Groningen. Andries willingly agreed to fulfil Meijer's wish and the Groningen conference placed ISINI back on the academic map, after which fruitful conferences would follow in Wroclaw, Poland, organized by Professor Joost Platje with the support of long-term active ISINI members, such as Francisco Vargas (former President) and secretary Johan van Ophem

Much to the liking of Andries Nentjes, as stated on its website (www.isini.info), ISINI is an international society composed of scholars and humanists in the areas of economics and the social sciences in general. It is devoted to the study of economic and financial thought, as well as current economic problems, such as economic and financial globalization, climate change, economic development, sustainable growth, structural change in resource distribution, capital and ideology, poverty, and the future of work (both paid and unpaid). Through the interaction and exchange of ideas and information among its members, as well as with non-attached scholars, it seeks to create or recreate alternative paradigms that can help to formulate adequate policies to solve those problems. The concept of intercommunication is preparing the ground for more interdisciplinarity and even for transdisciplinarity. ISINI stresses that all economic phenomena have their cultural, social, individual, political and moral dimensions, but the fundamental ones seem to be those that are intimately linked with human ends and the adequate means for fulfilling them. With this vision, Andries felt much at home at ISINI. 


\section{Edwin WOERDMAN, Yoram KROZER, Joost PLATJE}

\section{The memory remains}

Andries Nentjes was buried on the 22nd of March 2019 in Roden, after a memorial service in the local Catherina Church, where his wife, his children and Edwin Woerdman said a few warm words about his life, character and work. His sincere dedication to science, his seminal publications, his warm personality and his sense of humor will never be forgotten.

With the 14th International Meeting of ISINI held online in 2020 from Wroclaw, Poland, we honoured Professor Andries Nentjes by doing exactly what he always loved: fostering academic debate in a critical but friendly and supportive atmosphere.

\section{References}

Dijkstra B.R., Nentjes A. (2020), Pareto-efficient solutions for shared public good provision: Nash Bargaining versus Exchange-Matching-Lindahl, "Resource and Energy Economics", vol. 61, pp. 101179.

Koutstaal P., Nentjes A. (1995), Tradable carbon permits in Europe: Feasibility and comparison with taxes, "Journal of Common Market Studies", vol. 33 no. 2, pp. 219-233.

Krozer Y., Nentjes A. (2006), An essay on innovations for sustainable development, "Environmental Science", vol. 3 no. 3, pp. 163-174.

Kuipers S.K., Nentjes A. (1973), Pollution in a neo-classical world: The classics rehabilitated?, "De Economist”, vol. 121, pp. 52-67.

Nentjes A. (2017), Vijftig jaar milieueconomie, "Nieuwsbrief Milieu en Economie”, 13 oktober 2017.

Nentjes A. (1990), An economic model of transfrontier pollution abatement', in: Public finance, trade and development, ed. V. Tanzi (ed.), Wayne State University Press, Detroit MI, USA.

Nentjes A. (1977), Van Keynes tot Keynes: De ontwikkeling van het denken over geld en werkloosheid bij Keynes, Dissertation, University of Groningen.

Oosterhuis F. (2018), In memoriam Andries Nentjes, "Nieuwsbrief Milieu en Economie", 23 april 2018 .

Woerdman, E., Nentjes A. (2019), Emissions trading hybrids: The case of the EU ETS, "Review of Law and Economics", vol. 15 no. 1, pp. 1-32. 